\title{
大規模商業施設におけるデータ駆動型買い回り行動モデルの開発 \\ DEVELOPMENT OF DATA-DRIVEN AGENT MODEL FOR CONSUMER SHOPPING AROUND BEHAVIOR IN LARGE-SCALE COMMERCIAL FACILITY
}

\author{
安 福 健 祐 $^{* 1}$, 泉 本淳一*2, 阿部浩 和*3 \\ Kensuke YASUFUKU, Junichi IZUMOTO and Hirokazu ABE
}

\begin{abstract}
This study aims to develop a data-driven agent model to simulate consumer shopping behavior in a commercial facility. An agent-based simulation was conducted using the actual number of entering visitors, and the probability of transition between stores based on the purchase histories. As a result, it was possible to extract some characteristics of the stores that tended to be shopping around and visitor's circulation between floors. The reproducibility was verified by comparing the actual number of staying visitors, leaving visitors and visitors passing through the specific points in the passage.
\end{abstract}

Keywords: Data-Driven Model, Agent-Based Simulation, Commercial Facility, Shopping Behavior, Crowd Flow データ駆動型モデル，エージェントベースシミュレーション，商業施設，買い回り行動，群集流動

\section{1. はじめに}

日本ショッピングセンター協会 ${ }^{1)}$ によると、2019 年末における国 内のショッピングセンター（以下 SC）の総数は 3,219 施設であり、 2018 年末と比較して 16 年ぶりに減少し、日本の SC が転換期を迎え たといわれている。近年はインターネット通信販売をはじめ、消費 者の買い物行動が多様化していることも影響し、実店舗に求められ る役割が変化している。SCをはじめとする大規模商業施設において は、従来のモノ消費だけではなく、体験型のコト消費をきっかけと した購買行動が期待されており、顧客の滞在時間を延ばすことが売 上の増加につながるとして、商業施設内の回遊行動を促す空間構成 やテナント配置が重視される傾向にある ${ }^{2)}$ 。

一方、建築設計分野では ICT 技術の利用が進んでおり、各種のシ ミュレーション、AI 技術と組み合わせることによって、設計段階で 高度な空間性能評価を行うことが期待されている。シミュレーショ ン技術の一つであるエージェントベースシミュレーションは、複数 の人の行動を再現するもので、各人の動きに着目したミクロな視点 から群集流のマクロな視点までを考慮して空間の評価に利用される。 例えば、エージェントによって災害からの避難行動を再現すること で、建築・都市空間の避難安全性能が評価できるが、この場合の避 難行動は寸べてのエージェントが安全な場所に向かって移動する共 通の行動が設定される場合が多い ${ }^{3)}$ 。その一方、平常時の買い物行
動をモデル化して商業施設内の回遊行動をシミュレーションしよう とする場合、各人で目的が異なっており、その行動の根拠となるデ ータが必要となる。それに対して、近年はビッグデータを活用した 社会課題の解決、データ駆動型の研究を推進することで、イノベー ションの創出につなげることを目指した新たな科学の進め方が注目 されている ${ }^{4)}$ 。例えば、国土交通省では施策実施の効果を予測する ため、個人単位の行動データをもとに人の動きをシミュレーション して施設配置や空間形成、交通施策を検討する計画手法としてスマ ート・プランニングが推進されている5)。

大規模商業施設の買い回りをシミュレーションした研究として、 Mizuta $~^{6)}$ は、大規模エージェントシミュレーション環境をショッ ピングモールでの歩行購買に適用している。買い回りの店舗選択に は、 $\mathrm{Hui}^{7)}$ が提案した店舗、商品、通路にそれぞれ魅力度を設定した モデルを使用しているが、そのパラメータを決めるには実測調查が 必要となり、実際の店舗との比較には至っていない。長澤ら ${ }^{8}$ は、 買い物客の追跡および観察調查を行い、目的地がある状態と目的地 がない状態の二つの行動特性に分類し、時系列的に変化する買い物 客の状態や流動を表現するシミュレーションモデルを構築している。 しかしながら、買い回り行動の精度を高めるためには膨大な行動調 査が必要となり、実際の買い物客を対象にするには限界がある。一 方、石垣ら ${ }^{9)}$ は、百貨店 POS データ 1, 200 万件以上のレコードを利

\footnotetext{
大阪大学サイバーメディアセンター 准教授·博士 (工学)

2 竹中工務店 工修

Assoc. Prof., Cybermedia Center, Osaka Univ., Dr.Eng.

Takenaka Corporation, M.Eng.

大阪大学サイバーメディアセンター 教授・博士（工学）

Prof., Cybermedia Center, Osaka Univ., Dr.Eng.
} 
用して顧客の占舗内空間行動分析を試みている。ただし、ここでは フロア間の推移確率を算出して顧客属性要因を統計的に分析したも ので、回遊性などの空間特性を評価したものにはなっていない。

本研究は、大規模商業施設の一つである SC を対象として、会員力 ードの購入履歴を利用したデータ駆動型のアプローチにより買い回 り行動モデルを開発し、その妥当性を評価するとともに、買い回り 行動モデルをエージェントベースシミュレーションに適用すること で、SC 利用者の回遊性を再現することを目的としている。回遊性の 検証には実測データと比較して、その精度を向上させるためのパラ メータについて明らかにする。

本稿における買い回り行動モデルとは、SC 入館時の店舗選択確率 を含む店舗から店舗への選択確率（店舗間遷移確率と呼ぶ）および 出口を選択するときに複数の出口から一つを選択する確率で構成さ れた確率モデルと定義する。買い回り行動モデルを適用したエージ エントベースシミュレーション(以下、買い回りシミュレーション) は商用のソフトウェアを利用するが、会員カードの購入履歴から買 い回り行動モデルを生成するプログラムおよび買い回り行動モデル を含むシミュレーションの設定ファイルを生成するプログラムにつ いては新たに開発を行う。

\section{2. 方法}

\section{1. 対象}

対象とする SC は、店舗数 232 、店舗面積 68,640 平方メートル、 地上 4 階地下 1 階建てのエンクローズドモール（一部オープンモー ル）式 SC である。入手したデータには、（1）各出入口に設置された センサーで計測された入館者数および退館者数、(2) 会員カードに
よる各店舗の購入履歴、（3）通路の特定箇所における通過人数があ る 注 1)。Fig. 1 に SC の平面図を示す。各店舗に番号を割り振り注 2)、 共用の通路部分は灰色としている。（1）の出入口計測箇所と (3)の通 路計測箇所は平面図内に示している。

\section{2. 買い回り行動モデル}

SC 利用者の買い回り行動モデルを生成するため、会員カードの購 入履歴を利用する。会員カードは商品購入時にポイントが付与され るもので、1 ケ月あたり会員約 10 万人分の購入履歴を 30 万から 40 万件利用できる。購入履歴には会員番号、店舗名、購入日時、購入 金額などが含まれており、ここから SC 利用者の買い回り行動を抽出 する注3)。

\section{Extract time-series stores from purchase history in members cards} \#\#\#2
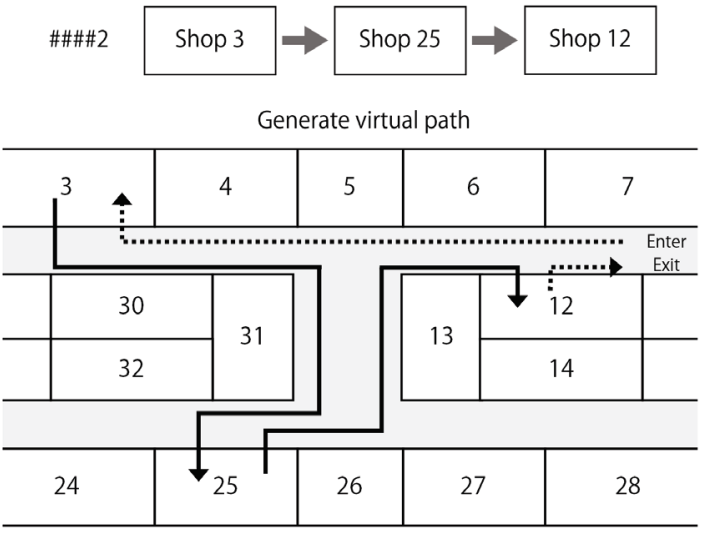

Fig.2 Virtual path based on purchase histories

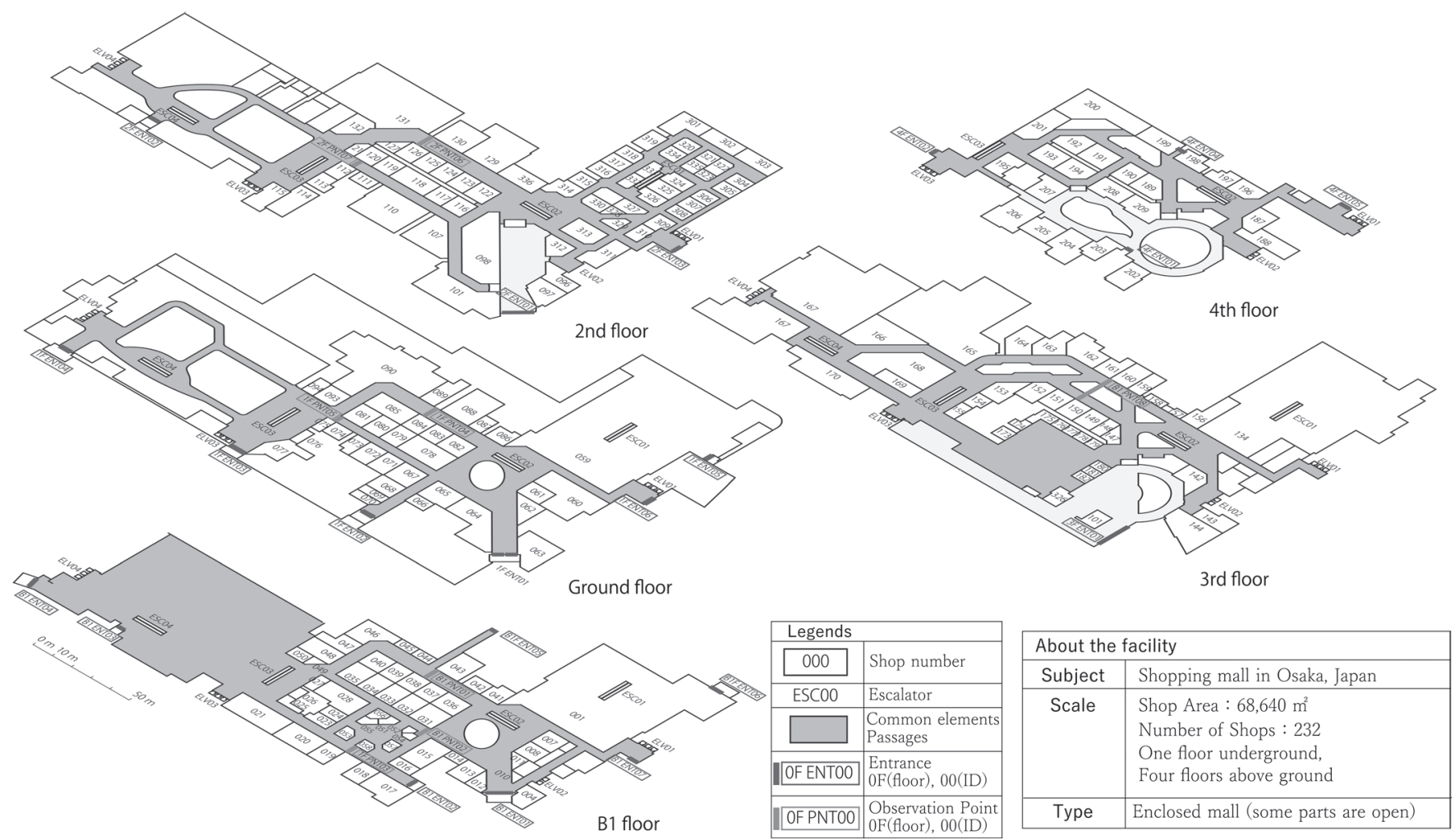

Fig.1 Plan of large-scale shopping center 
まず、SC 利用者が入館して最初に商品を購入した店舗 $i$ をすべて 抽出し、各店舗での購入回数 $N_{i}$ を店舗数 $n$ で除した值を入館時の店 舗選択確率 $P_{i}$ と寸る ( $i$ は各店舗に割り振られた番号注 2$)$ を示寸)。 次に店舗間の移動に着目する。ここでは買い物をした店舗の特徴の みが次に移動する店舗の選択確率に影響するマルコフ過程を仮定す る。そして、会員カードにおける複数の店舗の購入履歴から Fig. 2 のような仮想経路を想定する。この仮想経路はあくまで購入履歴が あった店舗のみで構成されており、立ち寄ったが何も購入しなかっ た店舗は含まれていない。しかしながら、1 度の来訪で 2 店舗以上 の購入履歴がある利用者は全体の約 $42 \%$ あ゙り、1 ケ月 10 万件以上 の仮想経路を作成することで、既往の追跡調査やアンケート調查な どの被験者数十から数百名程度のデータと比較して、統計的に信頼 性の高い店舗選択確率を抽出できると考える。そこで、ある会員が 店舗 $i$ で購入して次に店舗 $j$ で購入した履歴の合計 $\left(N_{i, j}\right)$ を、店舗 $i$ で購入した人の合計 $\left(N_{i}\right)$ で除した值を、店舗 $i$ から店舗 $j$ に移動寸 る店舗間遷移確率 $P_{i, j}$ として求める。ただし、SC の地下 1 階、 1 階、 2 階に接続している核店舗は会員カード対象外のため、核店舗の選 択確率は各階で可変のパラメータとする注4)。

退館する確率については、出口を一つの店舗とみなし、購入履歴 の最後は必ず出口に向かったとして店舗間遷移確率に含める。ただ し、各階に複数ある出口からどの出口を選択するかは入手したデー タからは不明であるため、入館した出入口は退館した出入口と同じ という仮定を行い、各出入口の入館者人数比率から退館する出口の 選択確率を設定する。

\section{3. 買い回りシミュレーション}

買い回りシミュレーションに用いるエージェントベースシミュレ ーションは、個々の人間をエージェントとして扱い、その動きをあ る一定のルールでモデル化し、エージェント同士またはエージェン 卜と空間の局所的な相互作用によって空間の回遊性を再現する。こ こでは各エージェントが移動するときの目的地選択に買い回り行動 モデルを適用する。買い回りシミュレーションには商用のソフトウ エア（Pathfinder）を利用する注5)。

当該ソフトウェアの特徵は、対象空間をナビゲーションメッシュ でモデル化して経路選択を行う点である。ナビゲーションメッシュ とは、エージェントが通行可能な領域が 3 次元メッシュ（三角形） の集合で表現されるため、正確な建物形状の再現に適している。経 路選択時は各メッシュをノード、隣接するメッシュとの接続関係を リンクとしたネットワーク構造から目的地までの移動時間をコスト とみなし、コストが最小になる経路（最小コスト経路）が計算でき る。建物情報を入力するときは居室単位でナビゲーションメッシュ をグルーピングし、隣接する居室は扉や階段、エスカレータで接続 する。こうすることで居室を退出するまでの経路と居室を退出して から目的地までのコストを別々に扱い、どちらを重視するかを重み 付けして経路選択を行うことができる。また、居室を退出するため に出口付近で他のエージェントが滞留している場合は、各エージェ ントがその待ち時間を予測して、待ち時間と移動時間の重み付けを したコストを算出し、コストが低い経路を選択させることもできる 注 6)。

ナビゲーションメッシュの経路選択によって目的地が決定される と、エージェントは目的地まで連続座標上を移動する。その途中に
エージェントはナビゲーションメッシュ境界線上の各点(Waypoint) を経由していくが、Waypoint 付近では 2 次の B スプラインによる曲 線上を滑らかに移動する (Fig. 3 参照)。また当該ソフトウェアにお いてェージェントと障害物またはエージェント同士の衝突回避には 力学ベースモデルが用いられている ${ }^{3)}$ 。

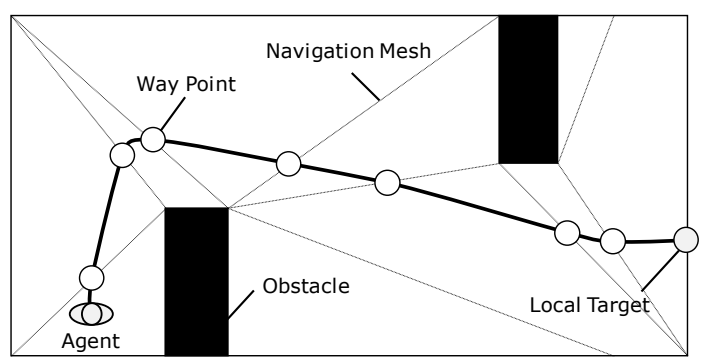

Fig.3 Moving path on navigation mesh

\section{4. シミュレーション設定}

買い回りシミュレーションに入力するデータは入館者数と店舗間 遷移確率に基づく買い回り行動モデルである。シミュレーションは $\mathrm{SC}$ が開店する午前 10 時から午後 1 時までの 3 時間とし、入館者数 は出入口に設置されたセンサーによって計測した入館者数を 1 時間 ごとに算出し 1 秒間に流入する人数に平均化した值を設定する。

Fig. 4 に 1 人のエージェントが入館し、店舗間を移動して退館す るまでのフローチャートを示す。実測值に基づいた人数のエージェ ントが各入口から入館すると、入館時の店舗選択確率 $P_{i}$ により最初 の目的地となる店舗に移動する。店舗に到着すると店舗の種類によ って一定時間滞在注 7) した後、店舗間遷移確率 $P_{i, j}$ により次の目的地 となる店舗に移動、滞在を繰り返す。選択された遷移先が出口の場 合は各出口の選択確率に従い、出口の一つまで移動して退館する。 尚、買い回り行動モデルにおける店舗間遷移確率は、店舗数 232 で 53, 824 通りにのぼることから、買い回り行動モデルを含むシミュレ ーション設定ファイルを自動生成するプログラムを新たに開発して いる。

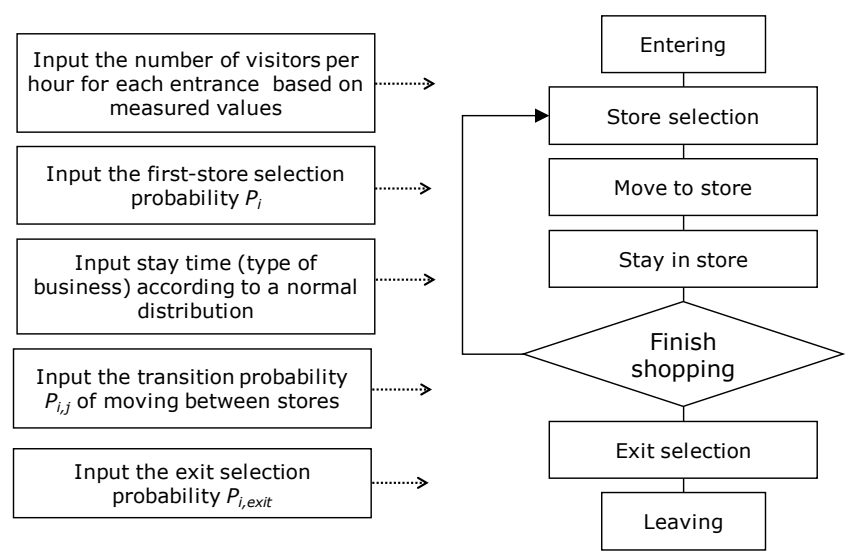

Fig.4 Simulation flow chart

買い回りシミュレーションにおけるエージェントの移動経路につ いては、各エージェントに買い回り行動モデルから目的の店舗が設 定されると、その店舗まではシミュレーションの最小コスト経路選 
択が適用される。このときナビゲーションメッシュ上を移動するた め、途中の経路に仮の目的地など設定する必要は生じない。

\section{5. 検証方法}

買い回り行動モデルを用いて SC 利用者の回遊性をシミュレーシ ヨンするにあたり、買い回り行動モデルの検証および買い回りシミ ユレーション結果の検証を以下のように行う。

まず、買い回り行動モデルの精度を検証するため、会員カードの 購入履歴データと同じ回数の買い回りを試行して、1 度に訪れる平 均店舗数を比較する。ただし、店舗間遷移確率は直前に買い物をし た店舗のみが次の店舗の選択確率に影響するマルコフ過程が仮定さ れているため、1 度の買い回りで同一店舗を選択する可能性が含ま れている。そこで、購入履歴データと買い回り行動モデルで同一店 舗を選択する確率の比較も行う。

次に、買い回りシミュレーションに関しては、実測データの一部 をシミュレーションの入力データに使用して、残りの実測データを シミュレーション結果注8) との比較に使用して検証を行う。入力に用 いる実測データは、各入口の入館者数の時系列データとする。シミ ユレーション結果の検証に用いるデータは、(1)館内の滞留者数注 9)、 (2) 各出口の退館者数、(3) 特定箇所の通路の通過人数の時系列デー タとする。(1)と (2) は買い回りのマクロな現象が再現されるもので、 買い回り行動モデルの精度が大きく影響する。(3) は SC 利用者の回 遊性が再現されるもので、その精度は各エージェントの経路選択が 大きく影響するが、シミュレーションの最小コスト経路選択では再 現が難しいと予想される。そのため、実測值に近づけるためのパラ メータ検討も行う。尚、シミュレーション結果は 1 秒単位で各結果 を出力できるが、実測值のほうは 1 時間毎に集計した人数となる。

\section{3. 結果と考察}

\section{1. 買い回り行動モデルの検証結果}

SC の会員カード購入履歴から生成した買い回り行動モデルにお いて、1 度の買い回りで訪れる店舗数を検証した。購入履歴データ には 171, 422 回の買い回りデータがあり、それと同じ回数を買い回 り行動モデルで試行した結果、買い回り行動モデルは平均店舗数が 2.77 店（標準偏差 1.15）であるのに対して、購入履歴データは平均 店舗数が 2.64 店（標準偏差 1.05）であり、高い再現性が確認でき た。さらに精度を向上させるためには、購入履歴に含まれていない 核店舗の購入履歴を入手する必要がある。

次に、買い回り行動モデルの店舗間遷移確率において、マルコフ 過程を仮定して 1 度の買い回りで同一店舗が選択されても、その再 現性に問題がないか検証を行った。まず、購入履歴データから 1 度 の買い回りで同一店舗を選択した回数を抽出したところ、買い回り 件数 171, 422 件のうち同一店舗を選択した回数が 1,234 回あり、そ の発生確率は $0.72 \%$ あった。次に、買い回り行動モデルで 171,422 回の買い回りを 10 回試行し、同一店舗を選択した回数を計測した。 その結果、同一店舗を選択した平均回数は 1, 148.4 回(標準偏差 21.3) あり、その発生確率の平均が $0.67 \%$ となった。この結果から、実際 の購入履歴データと買い回り行動モデルを比較して、同一店舗を選 択寸る回数は $90 \%$ 以上一致しており、店舗間遷移確率にマルコフ過 程を仮定しても同一店舗選択確率については高い精度が得られるこ とが確かめられた。

\section{2. 店舗間遷移確率}

買い回り行動モデルにおける入館時および店舗間遷移確率を図式 化したものをFig. 5 に示す。図は $215 \times 215$ の行列で確率が低ければ 白色で、高くなるほど灰色を濃く表現している。1行目 (Entrance) は入館時の店舗選択確率を示している。2 行目以降は 214 店舗の店 舗間遷移確率で移動元となる店舗番号が行に、移動先となる店舗番 号が列になり、例えば店舗 42 から店舗 134 一の遷移確率は $1.9048 \%$ となっている。右端の 215 列目は出口（Exit）の選択確率を表して おり、各店舗からも選択寸る確率は最も高くなる。

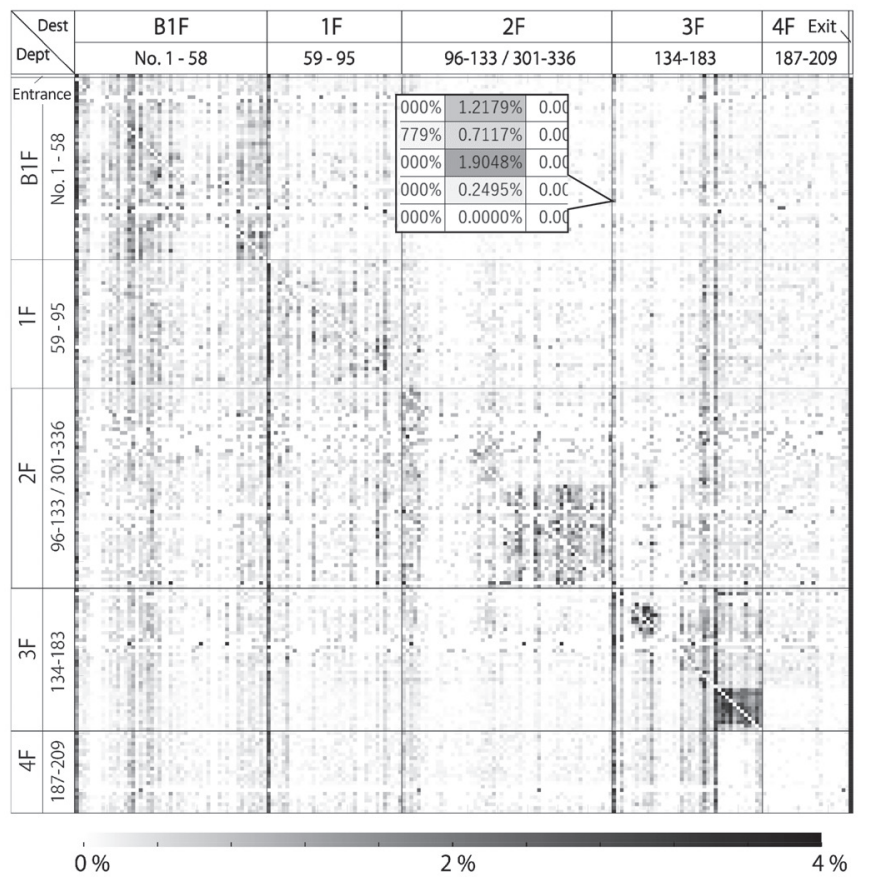

Fig.5 Transition probabilities between stores

店舗間遷移確率の特性として、縦 1 列に灰色が濃くなっている店 舗はどの店舗からも選択されやすいことを示す。これは入館時の店 舗選択確率が高い占舗とほぼ一致するが、一部でばらつきもみられ る。例えば、店舗 134 と店舗 167 は入館時に選択される確率が他の 店舗から選択される平均確率の 2 倍以上になっている。このような 店舗の利用者は、他の店舗に比べて入館時から購入目的がはっきり している傾向が読み取れる。一方、若年層向け服飾店が集合したエ リア（店舗 301-336）は 34 店舗中 29 店舗で最初に選択される確率 が他の店舗から選択される平均確率の 2 分の 1 以下になっている。 このような店舗は、各店舗の規模が小さく、そのエリア全体で大き な一つの店舗を構成しているともいえる。そのため、利用者は入館 時から特定の店舗に購入目的があるわけではなく、買い回りの結果、 購入に至る可能性が高い。

次に同一フロアにある店舗に着目すると、店舗間遷移確率は高く なる傾向にあり、特に 2 階の店舗 301 から 336 および 3 階の店舗 148 から 154 は同種の服飾店が集合したエリアでその傾向が顕著に現れ ている。また 3 階の店舗 172 から 183 はフードコートエリアの店舗 であり、店舗間遷移確率は高い傾向となる。その一方、4 階はレス トラン街のため店舗間を移動するということは少ない。異なるフロ ア間の遷移確率の傾向としては、どのフロアからも2 階へ向かう確 
率が相対的に低いことが読み取れる。

以上のことから、SCにおける買い回りが起こりやすい店舗の特性 や同一フロアおよびフロア間での回遊性の全体的な傾向を会員カー ドの購入履歴に基づく店舗間遷移確率を可視化して読夕取ることが できた。

\section{3. 買い回りシミュレーションにおける在館者数と退館者の推移}

買い回りシミュレーションにおける SC 内の滞留者数の推移と 1 時間毎の実測值を比較した結果をFig. 6 に示す。シミュレーション の人数が実測值よりも $10 \%$ から $15 \%$ 少なくなっているが、変化傾向は 概ね一致している。ただし、シミュレーションは 1 秒間隔で計測し た值であり、1 時間毎にグラフ変化傾向が異なる。この原因はシミ ユレーションに入力する入館者数が 1 時間毎の実測值を 1 秒あたり に平均化して流入係数を設定しているためであるが、全体の傾向を 把握する上で問題はないと考える。

次に退館者数の推移をシミュレーションと 1 時間毎の実測值で比 較した結果をFig. 7 に示す。こちらもシミュレーションの人数が実 測值よりも $9 \%$ から 13\%少なくなっているものの、変化傾向はよく一 致している。入館者数は実測值に基づいた人数であるが、滞留者、 退館者ともにシミュレーションのほうが少なくなるのは、シミュレ ーションの適用範囲外にある駐車場 (5 階, 6 階, 屋上) と駐輪場（地 下 1 階）からの入館者数（全体の約 $6 \%$ ）が考慮されていないため である。

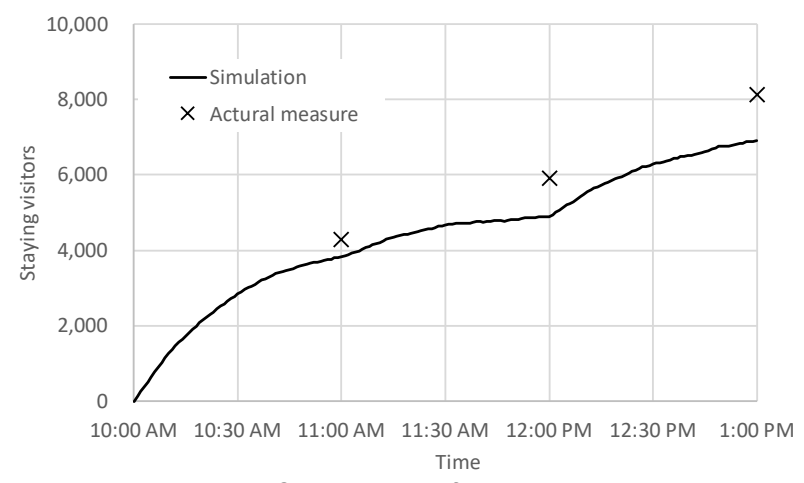

Fig.6 Comparison of staying visitors

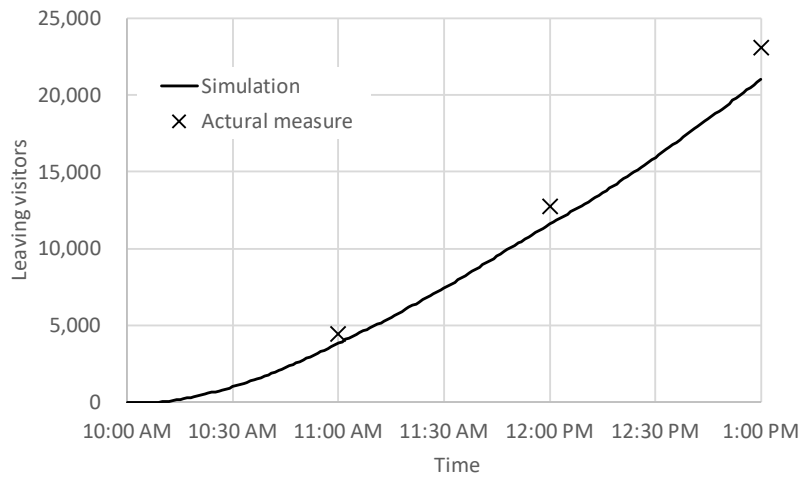

Fig.7 Comparison of leaving visitors

以上のことから SC 全体の滞留者数と退館者数というマクロな現 象については、今回の入館者数を入力データとした買い回り行動モ デルによるシミュレーションを用いて 85\%以上の精度で再現が可能 であることを示した。
各出口における退館者数のシミュレーション結果と実測值の比較 をFig. 8 に示す。買い回りシミュレーションは 10 時から 13 時まで 行っているが、時間が経過するほど現実とのずれが大きくなること から、最後の 1 時間である 12 時から 13 時の結果を比較している。 各出口の選択確率については、入館する出口が退館する出口と同じ という仮定に基づく選択確率で出口の一つを選択している。その結 果、シミュレーションと実測值との間の回帰直線が $=1.041 \mathrm{x}-22.284$ となって Y=X に近似しており、相関係数は 0.949 と高い精度が示さ れた。

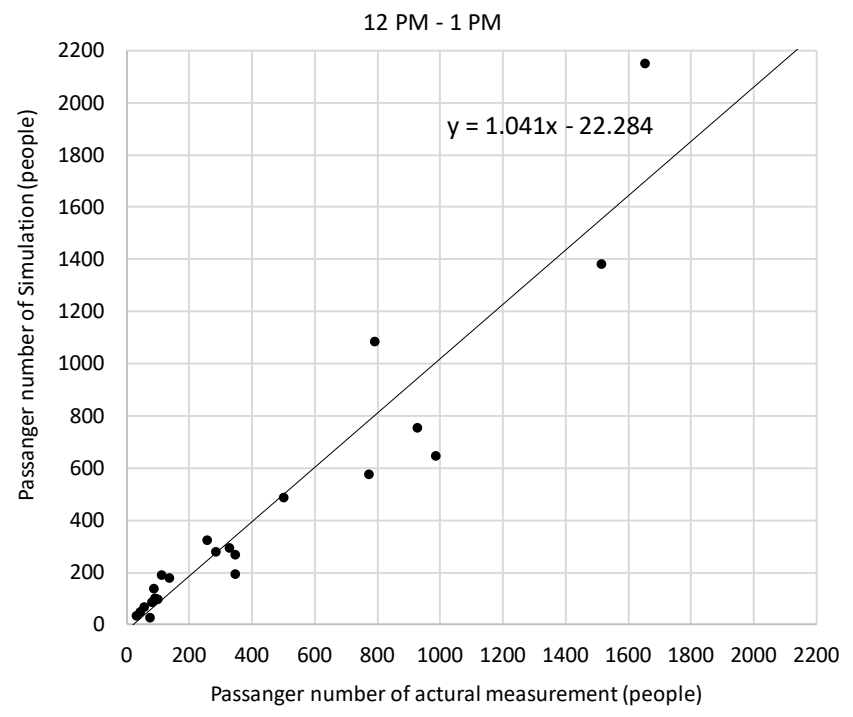

Fig.8 Comparison of leaving visitors at each exit

\section{4. 買い回りシミュレーションにおける通路の通過人数}

SC 内の通路 8 箇所の通過人数について、買い回りシミュレーショ ンと実測值で 1 時間ごとに比較した結果を Fig. 9 に示す。計測箇所 は地下 1 階に 3 箇所、 1 階に 2 箇所、2 階に 2 箇所、3 階に 1 箇所あ る。そのうち同一階に複数ある箇所に着目寸ると、通過人数に大き な差が生じており、シミュレーションは通路の回遊の再現性が低く なっている。この大きな要因の一つが、店舗間を移動するときにシ ミュレーションではエージェントが最小コスト経路で移動している ことが挙げられる。現実にはSC 内で目的の店舗に向かって最小コス 卜経路を移動するよりも、その途中に興味がある店舗を回りながら 移動することが多いと予想される。その場合に選択される経路は、 店舗の配置、通路の見通しや幅員、明るさ、開放性などといった距 離以外の要素も大きく影響することが考えられる。そこで実測值に 近づけるためのパラメータについて検討を行う。

買い回りシミュレーションにおける各エージェントの経路選択は ナビゲーションメッシュ上の最小コスト経路に基づく。コストの一 つは目的地に到達するまでに要する予測移動時間である。予測移動 時間は目的地までの距離を最大歩行速度で除した值で計算される。 最大歩行速度は、平地、階段、スロープごとに異なる速度が設定さ れる。さらにソフトウェアの仕様により、平地であっても各通路や 居室ごとに最大歩行速度を個別に設定することができる。ここでは、 実際の最大歩行速度を設定する目的としてではなく、通路の選択さ れやすさのパラメータとして、各通路における最大歩行速度を利用 
する。前節の結果から実測值よりもシミュレーションのほうが通行 人数の多かった「B1PNT02」「1FPNT05」「2FPNT07」の計測地点を含む 経路に最大歩行速度を減じる重み係数を設定する（Fig. 10）。

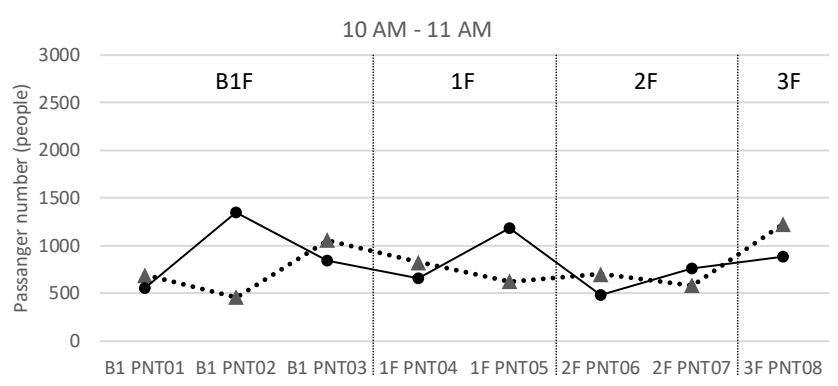
......Actural measurement $\longrightarrow$ Simulation

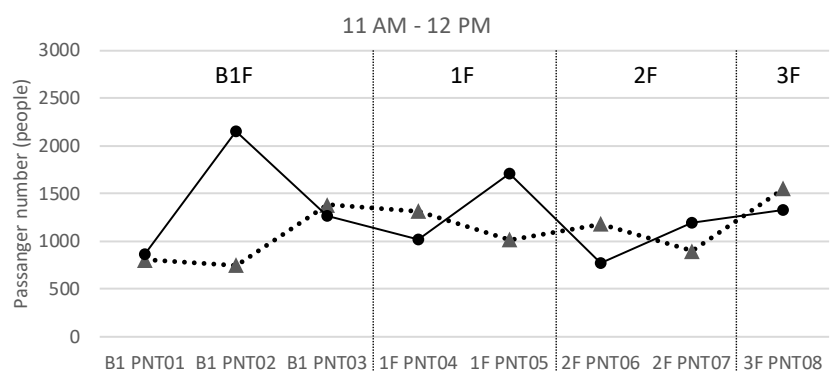
......Actural measurement $\longrightarrow$ Simulation

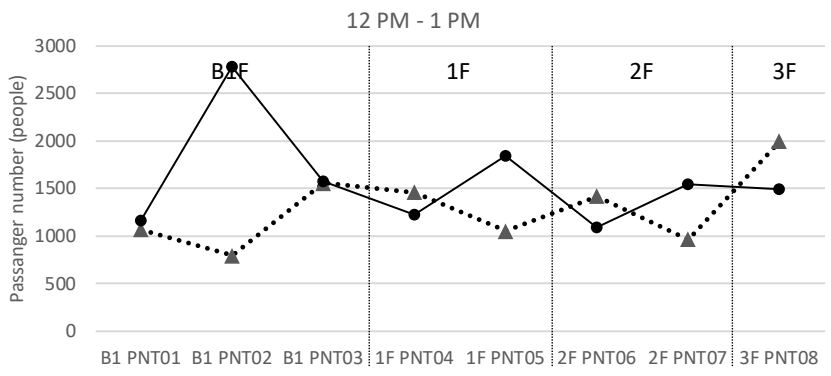
......Actural measurement $\longrightarrow$ Simulation

Fig.9 Comparison of passing visitors at certain points

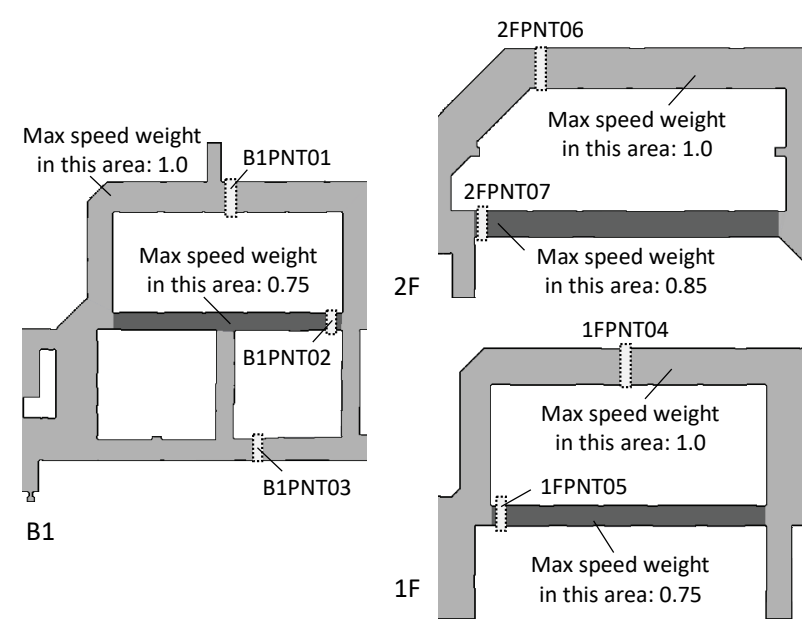

Fig.10 Parameter adjustment of max speed weight
パラメータ変更後の通路の特定箇所 8 箇所における通過人数をシ ミュレーションと実測で時間帯ごとに比較した結果をFig. 11 に示 す。
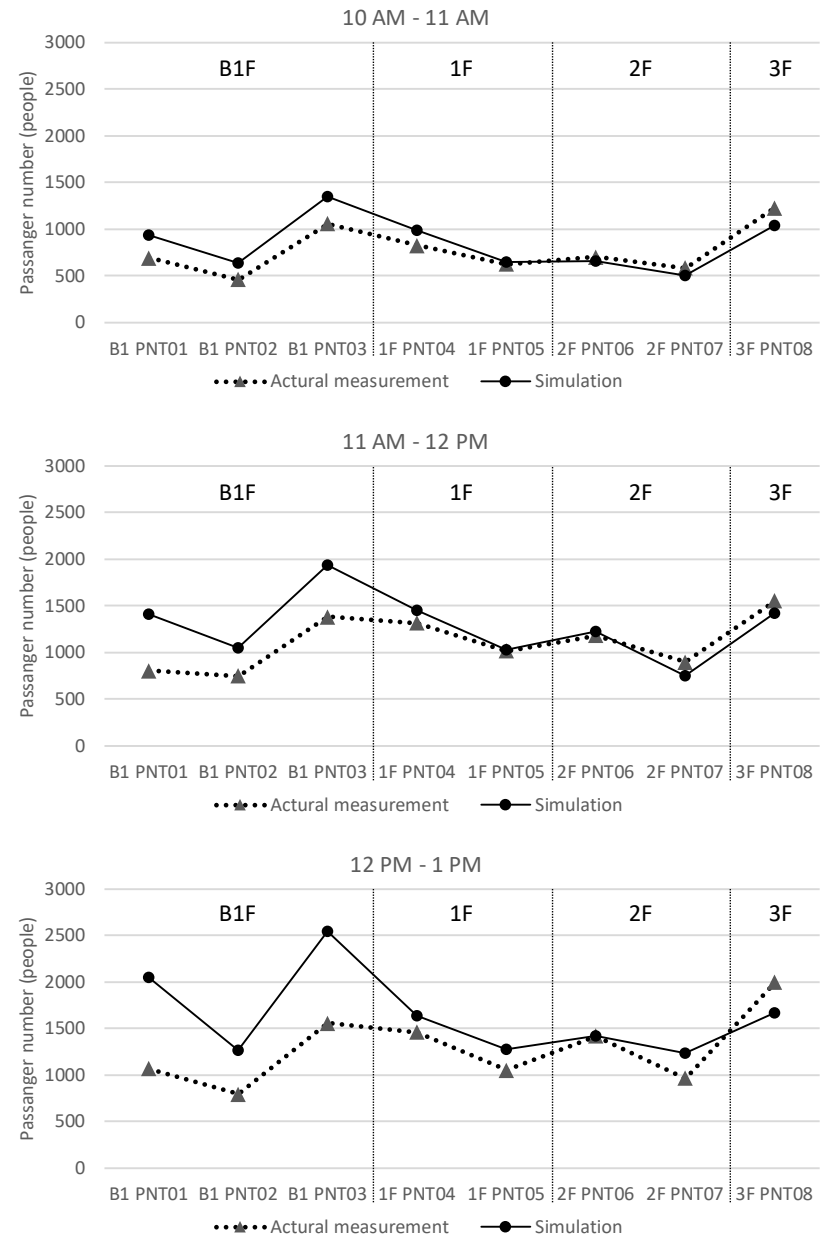

Fig.11 Parameter adjustment results of passing visitors

各通路の計測箇所における通過人数が Fig. 9 と比較して実測值に 近づく結果が得られた。午前 10 時から午前 11 時までの通行量の誤 差は最大 $38.1 \%$ (パラメータ調整前は最大 $250 \%$ )、各計測䇢所でシミ ユレーションと実測值のばらつきをみると相関係数が 0.806 (パラ メータ調整前は-0.24）と大きく改善した。しかし、午前 11 時から 午後 12 時までの通行量の誤差は最大 $75.5 \%$ で相関係数は 0.618 、午 後 12 時から午後 13 時までの通行量の誤差は最大 $92 \%$ で相関係数は 0.435 となり、時間が経過していくごとに誤差が大きくなっている。 特に地下 1 階の通行人数の差が時間経過とともに大きくなっている。 その要因としては、店舗間遷移確率は時間帯で変化しないこと、何 も買わなかった店舗や途中の休㮩など行動が考慮されていないこと、 店舗内の滞留時間が飲食店とそれ以外の 2 種類の值しか設定せず店 舗ごとの特性が考慮されていないこと、予測值で設定した核店舗の 選択確率の調整不足などが挙げられる。しかし、これらすべてのパ ラメータを実測值に基づき入力することは、そのデータの入手困難 性と機能が限定された商用のソフトウェアを用いる限界である。本 稿においては、入館者数と会員カードの購入履歴という入手可能だ が膨大にあるデータと商用のソフトウェアを組み合わせて、経路選 択のパラメータを調整することで、買い回りシミュレーション開始 
1 時間は各通路の通行量の誤差が最大でも $38.1 \%$ で実測值と一致し、 シミュレーションと実測值の間の各通路の通行量の相関係数は 0.806 と高い相関を示寸回遊性が再現された。

\section{5. 買い回りシミュレーション結果の可視化}

シミュレーション開始 1 時間 30 分後 (午前 10 時 30 分) の各フロ アのエージェントの分布およびエージェントがそれまでに通過した 箇所を可視化した結果を Fig. 12 に示す。平面図上で灰色が濃いとこ ろは利用者の通過が多かったことを表す。尚、買い回りシミュレー ションは通路における回遊性を評価することを目的にしており、店 舗内の回遊行動はシミュレーションの対象としていない。Fig. 12 は シミュレーションの見かけ上、店舗に到着したエージェントが店舗 内で滞留しているが、店舗の入口形状や家具レイアウトも考慮され ておらず正確な滞留性状を表すものではない。あくまで通路注 10)で の滞留（エスカレータ前の滞留を含む）をシミュレーションした結 果であるが、通路についてはその通過量を視覚的に把握することが できるため、パラメータ調整前後の比較や最適なパラメータに変更 するための指針を得ることができた。

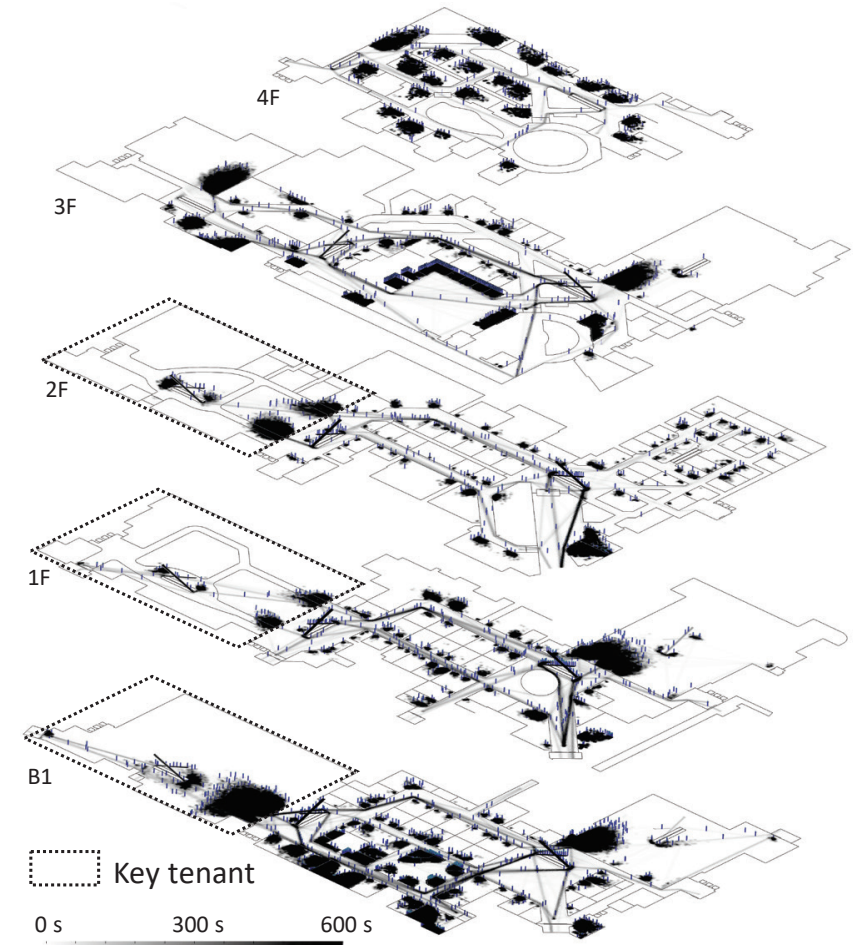

Fig.12 Visualization of simulation (1 hour and 30 min. passed)

\section{4. 結論}

本研究は、大規模商業施設の一つである SC を対象として、会員力 ードの購入履歴を利用したデータ駆動型のアプローチによる買い回 り行動モデルを開発し、エージェントベースシミュレーションに適 用することで以下の結果を得た。

（1）会員カード購入履歴により店舗選択確率を抽出し、店舗間遷 移確率に基づく買い回り行動モデルを開発した。

（2）買い回り行動モデルの精度を検証するため、1 度の買い回りで 訪れる平均店舗数を購入履歴データと比較した結果、購入履 歴データは平均店舗数が 2.64 店であるのに対して、買い回り
行動モデルは平均店舗数が 2.77 店となり、高い再現性が確認 できた。

（3）ママルコフ過程を仮定した店舗間遷移確率に基づく買い回り行 動モデルにおいて、同一店舗を選択する確率を検証した結果、 同一店舗を選択する回数は $90 \%$ 以上一致することを確かめた。

（4）SC の店舗間遷移確率を分析することで、入館時から購入目的 がはっきりしている傾向が読み取れる店舗と、入館時から購 入目的があるわけではなく買い回りの結果、購入に至る可能 性が高い店舗を明らかにした。

（5）店舗間遷移確率に基づく買い回り行動モデルをエージェント ベースシミュレーションに適用した結果、入館者数の実測值 を入力データにして、SC 全体の滞留者数と退館者数というマ クロな現象を $85 \%$ 以上の精度で再現した。

（6）シミュレーションでの各出口における選択確率は、入館する 入口が退館する出口と同じという仮定を行った結果、シミュ

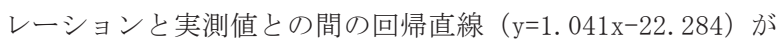
$\mathrm{Y}=\mathrm{X}$ とよく近似し、相関係数 0.949 となった。

（7）シミュレーションの店舗間の経路選択において、最小コスト 経路では通路通行量の再現性は低くなるが、通路ごとに経路 選択パラメータを調整することで、8 箇所ある通路の通行量の 利用率がシミュレーションと実測值で相関係数が -0.24 から 0.81 に改善した。

以上のことから、SCの会員カード購入履歴から生成された買い回 り行動モデルによって買い回りが起こりやすい店舗の特徴や、同一 フロアおよびフロア間での回遊性について評価を行うことができる ことを確かめた。さらに買い回り行動モデルと組み合わせたエージ エントベースシミュレーションにより滞留者数と退館者数のマクロ な現象は高い精度で一致し、各通路の通行量についてもパラメータ を調整することで再現性が大きく改善されることを示した。

会員属性による店舗間遷移確率の分析や属性別エージェントを用 いた買い回りシミュレーションの評価は今後の課題である。

\section{謝辞}

本研究は JSPS 科研費 JP19K04752, JST 未来社会創造事業 JPMJMI20D1, 東急不動産(株) および(株) 東急不動産 R\&D センターの 助成を受けたものである。記して感謝の意を表す。

\section{注}

注1）入館・退館者数の計測および特定の通路の通過人数の計測は 2018 年 10 月 14 日の休日 1 日を対象とした。会員カードによる購入履歴は 2019 年 2 月の 1 ケ月分のデータを用いる。

注2）店舗番号は 1 から 209 および 301 から 336 の範囲で設定しており、これ までの店舗入れ替えや期間限定店舗の影響で久番になっているものも ある。

注3)会員カードによる購入履歴の抽出にはプログラム言語 Python と Python 用データ解析オープンソースライブラリPandas を利用した。会員カード の属性として男性 9, 031 名、女性 78, 172 名、平均年齢 42. 6 歳である。1 日あたり 1 店舗のみの購入履歴は 102,457 件（全体の $59.8 \%$ ）、2 店舗 39,537 件、 3 店舗 16,515 件、 4 店舗 6,933 件、 5 店舗以上が 5,980 件で ある。

注4) 核店舗各階の選択確率は、1 階 7\%、2 階 $2 \% 、 3$ 階 4\%と設定した。核店 舗の選択確率に関しては、会員カードの購入履歴にその情報が含まれて いないため、以下の過程で推定を行った。核店舖における 2019 年 2 月の レジ利用回数データを別途入手したところ、レジ利用回数が 351,970 回 
あり、1 日あたりの平均レジ利用回数 12,570 回と設定する。一方、2019 年 2 月の入館者数は 1 日あたりの平均 77,993 人である。このことから約 $16 \%$ 入館者が核店舗で買い物をしたとみなし、3フロアある核店舗の各 フロアに対し $5 \%$ の選択確率を設定した。そこから核店舗の各フロアの店 舗特性を考慮しながら、士1\%ずつ確率を変更して数回のシミュレーショ ンを実行した中から再現性が最も高くなる值を推定值とした。

注5) Pathfinder によるシミュレーションで使用するパラメータとして、エー ジェントの大きさは直径 $45.58 \mathrm{~cm}$ の円形、最大歩行速度は $1.19 \mathrm{~m} / \mathrm{s}$ 、 その他の経路選択に必要なパラメータについてもソフトェアの初期值を 用いており、值の根拠についてはPathfinder の技術解説書 ${ }^{10)}$ を参照され たい。尚、エージェントは他者および障害物等との衝突を回避した結果、 減速や滞留が生じることはある。

注6) 買い回りシミュレーションにおいては、コストの重み付けは初期設定 (す ベて 1.0）を用いる。

注7) 店舗の滞在時間は飲食店舗の場合平均 1,800 秒、標準偏差 300 秒、飲食 店舗以外の場合平均 400 秒、標準偏差 50 秒の正規分布に基づく疑似乱数 の值とする。

注8)シミュレーションにおける経路選択には店舗間遷移確率を用いるため、 その結果にばらつきが出るはずであるが、Pathfinder の仕様上、確率に 用いられる疑似乱数の初期值が同じとなり、繰り返した結果に差は生じ ないことを確認した。

注9) 滞留者数の実測值は、各出入口に設置されたセンサーで計測された入館 者数および退館者数が 1 時間ごとに集計されており、その全入館者数か ら全退館者数を引いた值とする。

注10）Fig. 12 の点線の四角で示したエリアは核店舗を示しており、シミュレ ーション上は一つの店舗とみなされるため核店舗にみられる通路形状 は考慮されない。

\section{参考文献}

1) Japan Council of Shopping Centers: SC opened in 2019 (Table), 2019.12 (in Japanese, accessed June 20, 2020)

一般社団法人日本ショッピングセンター協会：2019 年オープン SC（一覧 表），2019. 12

http://www. jcsc. or. jp/sc_data/sc_open/2019opensc(参照 2020.6. 20)

2) Station Consumer Research Center: EKISUMER, Vol.37, 2018.7 (in Japanese)

駅消費研究センター：エキシューマー 特集「駅ビルの回遊行動を考え る」, Vol. 37, 2018.7

3) Yasufuku, K.: Analysis of Crowd Walking Using Evacuation Behavior Framework and Application to Evacuation Safety Verification, Journal of Architecture and Planning (Transactions of AIJ), Vol.75, No.655, pp.2081-2088, 2010.9 (in Japanese)

安福健祐：避難行動フレームワークを用いた群集歩行モデルの比較分析 と避難安全検証一の適用性, 日本建築学会計画系論文集, 第 75 巻, 第 655 号, pp. 2081-2088, 2010.9

4) OECD: Data-Driven Innovation Big Data for Growth and Well-Being, OECD Publishing, 2015.10

5) Ministry of Land, Infrastructure, Transport and Tourism: Smart Planning Guide -New Town Planning Based on Individual Behavior Data-, 2018.9 (in Japanese, accessed June 20, 2020)

国土交通省都市局都市計画課都市計画調査室：スマート・プランニング 実践の手引〜個人単位の行動データに基づく新たなまちづくり〜, 2018.9

https://www. mlit. go. jp/common/001255680.pdf（参照 2020.6.20)

6) Mizuta, H.: Large-Scale Distributed Agent-Based Simulation for Shopping Mall and Performance Improvement with Shadow Agent Projection, Proceedings of the 2017 Winter Simulation Conference, pp.1157-1168, 2017.12

7) Hui, S. K., Bradlow, E. T., Fader, P. S.: Testing Behavioral Hypotheses Using an Integrated Model of Grocery Store Shopping Path and Purchase Behavior, Journal of Consumer Research, Vol.36, Issue 3, pp.478-493, 2009.10

8) Nagasawa, N., Sako, T., Watanabe, H.: Shopping Behavioral Model for Large-Scale Commercial Facilities Planning, Journal of Architecture and Planning (Transactions of AIJ), Vol.74, No.646, pp.2611-2616, 2009.12 (in Japanese)
長澤夏子, 佐古崇, 渡辺仁史：大規模商業施設計画のための買い物行動 モデル, 日本建築学会計画系論文集, 第 74 巻, 第 646 号, pp. 2611-2616, 2009. 12

9) Ishigaki, T., Ozawa, K.: Analysis of In-Store Space Customer's Behavior Using POS Data of Department Store, Operations Research as a Management Science Research, Vol.50, No. 3, pp.181-186, 2005.3(in Japanese)

石垣智徳，小沢佳奈：百貨店 POS データによる顧客の店舗内空間行動分 析, オペレーションズ・リサーチ: 経営の科学, 第 50 巻, 第 3 号, pp. 181-186, 2005.3

10) Thunderhead Engineering Consultants Inc.: Pathfinder Technical Reference, 2017

https://www.thunderheadeng.com/files/com/pathfinder/tech_ref.pdf (accessed June 20, 2020) 


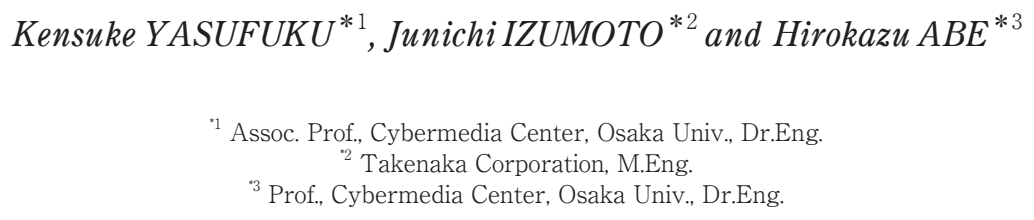

The use of ICT is becoming common in architectural design. It is expected that the increasing use of simulations and various AI technologies will lead to further improvements in the evaluation of spatial performance during the design stage. This study develops a data-driven agent model to simulate consumer shopping behavior in a large-scale commercial facility, with the ultimate aim of identifying the optimal store arrangement and passage shape. The subject commercial facility is a shopping center with 232 stores and 68,640 square meters of floor space. Four stories of the facility are above ground and one story is below. The data obtained from the facility and used in the model included (1) the number of entering/exiting visitors, (2) the purchase histories of membership cardholders, and (3) the number of visitors passing various points in the facility's passageways. The membership cards of shoppers gave the authors access to 300,000 to 400,000 purchase histories of approximately 100,000 cardholders per month. To model consumer shopping behavior, the transition probabilities of moving between stores were generated from the available purchase histories. The results are as follows.

Two types of stores were identified by analyzing the $215 \times 215$ matrix of store-to-store transition probabilities generated from the available purchase histories. The first type includes stores targeted by visitors whose have a clear purpose upon entering the SC. The second type includes stores where visitors tend to make purchases as a result of shopping around rather than having a clear purchase objective in mind immediately upon entry to the facility. The between-store transition probabilities involving stores on the same floor tended to be relatively high, especially in the food court area and the area where similar clothing stores was clustered. On the other hand, the transition probabilities involving stores on different floors tended to be relatively low, particularly the probabilities of going from the first basement floor, the third floor, and the fourth floor to the second floor.

The simulation was generally successful in reproducing macroscopic phenomena such as the number of visitors staying and leaving the SC by using the number of entering visitors and the between-store transition probabilities as input data. The exit-selection probabilities showed a high degree of reproducibility under the assumption that the exit used by leaving visitors would be the same as the entrance they had used. The ability of the simulation to reproduce passage use was rather low when it was assumed that the visitor would select only the shortest route to move from one store to another. However, the simulation results more closely approximated the measured values when the route selection parameters for some of the passages were adjusted. 